UDC 612-06

DOI: $10.21668 /$ health.risk/2020.3.07.eng

Research article

\title{
HYGIENIC ASSESSMENT OF AEROGENIC EXPOSURE TO PARTICULATE MATTER AND ITS IMPACTS ON MORBIDITY WITH RESPIRATORY DISEASES AMONG CHILDREN LIVING IN A ZONE INFLUENCED BY EMISSIONS FROM METALLURGIC PRODUCTION
}

\author{
I.V. Tikhonova ${ }^{1}$, M.A. Zemlyanova ${ }^{2}$, Yu.V. Kol'dibekova ${ }^{2}$, E.V. Peskova ${ }^{2}$, A.M. Ignatova ${ }^{2}$ \\ ${ }^{1}$ Federal Service for Surveillance over Consumer Rights Protection and Human Wellbeing, Krasnoyarsk Region \\ office, 21 Karatanova Str., Krasnoyarsk, 660049, Russian Federation \\ ${ }^{2}$ Federal Scientific Center for Medical and Preventive Health Risk Management Technologies, 82 Monastyrskaya Str., \\ Perm, 614045, Russian Federation
}

\begin{abstract}
At present an outstanding task is to concentrate on chemical and fractional structure when examining and assessing influence exerted by particulate matter on morbidity among children. The main goal of any such research is to prevent negative effects produced on the respiratory organs.

Our research objects were ambient air in residential areas contaminated with particulate matter that were components in emissions from non-ferrous metallurgic enterprises (the test territory) and ambient air in residential areas free of such contamination; morbidity among children was also given our attention.

Our assessment of ambient air quality as per $P M_{10}$ and $P M_{2.5}$ contents revealed they exceeded the standards recommended by the WHO and were by 1.4 times higher than recommended MPCa.d. Respirable fraction of particulate matter tends to have complicated chemical structure and contains metals that are specific for emissions from metallurgic enterprises such as nickel, copper, iron, aluminum, titanium, gallium, and neodymium. The latter can enhance negative effects produced by particulate matter on the respiratory organs. Epidemiologic assessment in a contaminated zone (the test territory) allowed establishing 1.8 times higher general and primary morbidity as per respiratory organs diseases than on the reference territory; it was even up to 14.8 times higher as per specific nosologies such as chronic disease of tonsils and adenoids, asthma, and status asthmaticus. We also established authentic dependence between probability of respiratory diseases and elevated concentrations of particulate matter in ambient air.

Results of the proven dependence allow predicting up to 500/1000 additional respiratory diseases cases per year on the test territory; all these additional morbidity cases among children are associated with aerogenic exposure to particulate matter.

Key words: ambient air, particulate matter, $P M_{10}, P M_{2.5}$, respiratory organs, children, additional morbidity.
\end{abstract}

Industrial complexes operating in nonferrous metallurgy which are located in RF regions are, as a rule, large objects both in terms of production volumes and masses of contaminants emissions into ambient air [1]. Dust and gas mixtures discharged from metallurgic productions include commonly spread gaseous substances (sulfur, nitrogen, and car-

(C) Tikhonova I.V., Zemlyanova M.A., Kol'dibekova Yu.V., Peskova E.V., Ignatova A.M., 2020

Irina V. Tikhonova - Head of the Department for Social and Hygienic Monitoring (e-mail: tihonova_iv@, 24.rospotrebnadzor.ru; tel.: +7 (391) 226-89-91; ORCID: http://orcid.org 0000-0003-4111-8454).

Marina A. Zemlyanova - Doctor of Medical Sciences, Chief Researcher acting as the Head of the Department for Biochemical and Cytogenetic Diagnostic Techniques (e-mail: zem@fcrisk.ru; tel.: +7 (342) 236-39-30; ORCID: http://orcid.org/0000-0002-8013-9613).

Yuliya V. Kol'dibekova - Candidate of Biological Sciences, Senior researcher acting as the Head of the Laboratory for Metabolism and Pharmacokinetics at the Department for Biochemical and Cytogenetic Diagnostic Techniques (e-mail: koldibekova@fcrisk.ru; tel.: +7 (342) 237-18-15; ORCID: http://orcid.org/0000-0002-3924-4526).

Ekaterina V. Peskova - Junior researcher at the Laboratory for Biochemical and Nano-sensory Diagnostics of the Department for Biochemical and Cytogenetic Diagnostic Techniques (e-mail: peskova@fcrisk.ru; tel.: +7 (342) 236-39-30; ORCID: https://orcid.org/0000-0002-8050-3059).

Anna M. Ignatova - Researcher (e-mail: iampstu@gmail.com; tel.: +7 (342) 236-39-30; ORCID: http://orcid.org/ 0000-0001-9075-3257). 
bon oxides), specific compounds (iron, manganese, nickel, lead, aluminum, etc.), and particulate matter as well. Dust emissions make a substantial contribution into ambient air contamination in residential areas. Effects produced by particulate matter can result in negative consequences for health, first of all, respiratory diseases. Effects are especially hazardous for children since protective and adaptation capabilities of children's bodies are underdeveloped $^{1}[2]$.

The World Health Organization (WHO) ranks particulate matter including fine-disperse particles sized 2.5 and $10 \mu \mathrm{m}$ among priority contaminants according to gravity of the effects they produce on population health [3]. According to WHO recommendations, average daily maximum permissible concentration for $\mathrm{PM}_{2.5}$ in ambient air is $0.025 \mathrm{mg} / \mathrm{m}^{3}$; for $\mathrm{PM}_{10}$, $0.05 \mathrm{mg} / \mathrm{m}^{3}$, and it is 1.4 and 1.2 times stricter than corresponding hygienic standards existing in the Russian Federation ${ }^{2}$. Chemical structure of particulate matter emitted by metallurgic enterprises depends on peculiarities of technological processes applied at them and includes various non-organic components, primarily metals [4-6]. Research works that dwell on assessing influence exerted by particulate matter on population health contain data on a wide range of negative effects, including those produced on respiratory organs and resulting in more frequent bronchitis cases and other symptoms in upper and lower respiratory tracts, exacerbated asthma attacks, more frequent pneumonias and greater mortality due to respiratory diseases [7]. The largest-scale epidemiologic research performed on 22 population cohorts in Europe confirmed dependence between total mortality and $\mathrm{PM}_{2.5}$ concentrations in ambient air; mortality grew by $7 \%$ per each $5 \mu \mathrm{g} / \mathrm{m}^{3}$ [8].

As per data provided by the WHO, ambient air contamination with fine-disperse particulate matter produces apparent negative ef- fects directly on respiratory tracts. Particles with aerodynamic diameter being less than $10 \mu \mathrm{m}$ are proven to be able to penetrate via the bronchial tree and accumulate in lung tissues; PM with their diameter less than $2.5 \mu \mathrm{m}$ are able to reach bronchioles and alveoli; PM with their diameter being less than $0.1 \mu \mathrm{m}$ can even penetrate the blood flow $[4,6,9,10]$. Experimental research works allowed establishing than effects produced by $\mathrm{PM}_{2.5}$ on the respiratory tract mucosa resulted in a decrease in chalice cells number and epithelium thickness [11]. These changes lead to a reduction in phagocytes macrophages and epithelial cells that participate in protective functions performed by respiratory tracts and aimed at protection from negative effects produced by contaminants in ambient air [6].

Multiple Russian and foreign research works contain evidence that there is a direct correlation between a significant growth in respiratory diseases and additional cases of diseases in the respiratory organs and effects produced by particulate matter in ambient air [7, 12-14]. It is well-proven that when average daily $\mathrm{PM}_{10}$ concentration grows by $10 \mu \mathrm{m} / \mathrm{m}^{3}$, there is a $2.4-3.4 \%$ growth in application for medical aid or admission to hospitals among population due to diseases of the upper and lower respiratory tracts, and bronchitis cases number grows by $10-25 \%[15,16]$. When $\mathrm{PM}_{10}$ concentration grows by $10 \mu \mathrm{m} / \mathrm{m}^{3}$ during 2 months, frequency of bronchial asthma attacks among children increases by $4.2 \%$ [16].

At present it is vital to examine and assess negative effects produced by particulate matter on morbidity among children taking into account their chemical and fraction structure as it allows working out efficient preventive activities aimed at reducing or eliminating negative consequences for respiratory organs.

Our research goal was to hygienically assess aerogenic exposure to particulate matter and effects produced on morbidity with

\footnotetext{
${ }^{1}$ On sanitary-epidemiologic welfare of the population in the Russian Federation in 2018: the State report. Moscow, The Federal Service foe Surveillance over Consumer Rights Protection and Human Wellbeing Publ., 2019, 254 p. (in Russian).

${ }^{2}$ HS 2.1.6.3492-17. Maximum permissible concentrations (MPC) of contaminants in ambient air in urban and rural settlements: The Order by the RF Chief Sanitary Inspector issued on December 22, 2017 No. 165. KODEKS: an electronic fund for legal and reference documentation. Available at: http://docs.cntd.ru/document/556185926 (07.02.2020) (in Russian).
} 
respiratory deceases among children living in a zone exposed to emissions from metallurgic enterprises.

Data and methods. The research objects were ambient air samples taken in residential areas where ambient air was contaminated with particulate matter due to emissions from enterprises operating in non-ferrous metallurgy (the test territory) and in residential areas without such contamination (the reference territory) and databases with data on morbidity among children.

Fraction and chemical structure of particulate matter was examined via analyzing daily ambient air samples taken at a point located $2 \mathrm{~km}$ away from the boundary of a sanitaryprotection zone around a metallurgic enterprise. Samples were taken over a period of time starting from 00.30 to 18.30 with PA-300M-2 air intake device (Russia) on AFA-VP-20-2 filters (Russia). Granulometric structure of particulate matter was examined via analyzing images obtained with S-3400N electronic scanning microscope (Hitachi, Japan) with Image J-FiJi software (Germany); chemical structure was examined via $\mathrm{X}$-ray analysis performed with $\mathrm{X}$ Flash Detektor 4010 energy-dispersive spectrometer (Bruker, Germany).

Hygienic assessment of particulate matter contents including their $\mathrm{PM}_{2.5}$ и $\mathrm{PM}_{10}$ fractions in ambient air samples was performed according to HS 2.1.6.3492-17 «Maximum permissible concentrations (MPC) of contaminants in ambient air in urban and rural settlements») by experts from the Collective Use Center at the Perm State Research Polytechnic University.

We comparatively assessed overall and primary morbidity with respiratory diseases among children (younger than 14) on the test and reference territories using data from the Federal Statistic Report Form No 12 «Data on number of diseases registered among patients living on a territory where medical services were rendered by a particular medical organization» over 2014-2018 and results obtained via analyzing data on actual application for medical aid provided by the Regional Fund for Obligatory Medical Insurance over 2017-2018. All the cases when exposed and non-exposed population applied for medical aid were bound to specific locations on maps of both residential areas. We performed spatial intersection with ArcGIS 9.3 software to establish number of children exposed to chemical factors that were tropic to respiratory organs.

Data were statistically analyzed with Statistica 6.0 software package and specific software packages with MS-Office applications. Normalcy of measured variables distribution was tested with Kolmogorov-Smirnov test. To quantitatively characterize the examined parameters, we used mean value and error of mean since random variables of analyzed parameters conformed to normal distribution. Validity of discrepancies in morbidity among children population on the test territory and the reference one was performed with Student's t-test. Statistical significance was taken as $p \leq 0.05$ [17].

We revealed and assessed cause-and-effect relations between probability of respiratory diseases occurrence and particulate matter content in ambient air with help provided by experts from the Department for Mathematic Modeling of Systems and Processes at the Federal Scientific Center for Medical and Preventive Health Risk Management Technologies; it was done via simple linear regression analysis.

We assessed whether a regression model was authentic and relevant using significance $(p)$ and correlation coefficient $(r)$. Statistical significance was tested according to conventional procedure for statistic hypothesis testing based on Student's t-test $(t)$ calculation [18].

Results and discussion. Emissions from metallurgic enterprises contain more than 80 different chemicals. Particulate matter and metal oxides that occur in their structure account for approximately $20 \%$ of the overall emission masses.

Having assessed fractional structure of particulate matter, we revealed that PM were emitted into ambient air on the test territory and particles with their diameter being 2.5-10.0 $\mu \mathrm{m}$ accounted for approximately $57.0 \%$ of the overall particles number. Particles with diameter $0.1-2.5 \mu \mathrm{m}$ accounted for $21.0 \%$; particles with diameter being smaller than $0.1 \mu \mathrm{m}$ accounted for $22.0 \%$ (Table 1 ). 
Table 1

Fraction structure and average daily concentration of particles with different sizes; particles were deposited on filters when ambient air on residential areas was examined

\begin{tabular}{|c|c|c|c|c|c|c|}
\hline \multirow[b]{2}{*}{$\begin{array}{l}\text { Particles size } \\
\text { range, } \mu \mathrm{m}\end{array}$} & \multirow[b]{2}{*}{$\underset{\mathrm{mg} / \mathrm{m}^{3}}{\text { MPav.d* }}$} & \multirow[b]{2}{*}{$\begin{array}{c}\text { MPCav.d. } \\
\mathrm{mg} / \mathrm{m}^{3}\end{array}$} & \multicolumn{2}{|c|}{ Test territory } & \multicolumn{2}{|c|}{ Reference territory } \\
\hline & & & $\begin{array}{l}\text { Particles } \\
\text { share, \% }\end{array}$ & $\begin{array}{c}\text { Average daily } \\
\text { particles concentra- } \\
\text { tion, } \mathrm{mg} / \mathrm{m}^{3}\end{array}$ & $\begin{array}{l}\text { Particles } \\
\text { share, \% }\end{array}$ & $\begin{array}{c}\text { Average daily } \\
\text { particles concentra- } \\
\text { tion, } \mathrm{mg} / \mathrm{m}^{3}\end{array}$ \\
\hline less 0,1 & - & - & 22.3 & 0.018 & 2.2 & 0.002 \\
\hline $0,1-2,5($ & 0.035 & 0.025 & 20.8 & 0.034 & 79.88 & 4 \\
\hline $2,5-10,0\left(\mathrm{PM}_{10}\right)$ & 0.06 & 0.05 & 56.9 & 0.057 & 17.87 & 0.014 \\
\hline
\end{tabular}

Note:

* is average daily maximum permissible concentration of a substance as per Hygienic Standard 2.1.6.3492-17

${ }^{* *}$ is average daily maximum permissible concentration of a substance as per EU Directive.

It should be noted that a share of particles with their aerodynamic diameter being $2.5-10 \mu \mathrm{m}$ and less than $0.1 \mu \mathrm{m}$ was by $3.0-10.0$ times higher in ambient air on the test territory than on the reference one.

We assessed $\mathrm{PM}_{10}$ and $\mathrm{PM}_{2.5}$ contents in ambient air in residential areas on the test territory; the assessment revealed that average daily concentrations fixed in Russian hygienic standards were not violated. But still, the occurring concentrations were 1.2 and 1.4 times higher than average daily maximum permissible concentrations recommended by the WHO and also 1.4 and 4.0 times higher than the same parameters on the reference territory.

Chemical structure of fine-disperse particles with different sizes is rather complicated and includes approximately 15 metal and non-metal oxides. And most metals that occur in particles (iron, nickel, copper, titanium, gallium, and neodymium) are typical for emissions from metallurgic production (Table 2).

Ambient air samples taken on the test territory more frequently contain fine-disperse particles with commonly spread sodium oxides in their structure, their mass fraction varying from 1.5 to $7.1 \%$, and oxides that are specific for metallurgic production, such as copper, iron, nickel, and titanium oxides, their mass fraction varying from 0.16 to $6.5 \%$; titanium, gallium, and neodymium oxide are less frequent with their mass fraction varying from 0.6 to $11.9 \%$ and they are completely absent in the structure of fine disperse particles contained in ambient air samples taken on the reference territory. Figures 1 and 2 give examples of spectrograms showing chemical structure of a specific finedisperse particle and its electronic image.

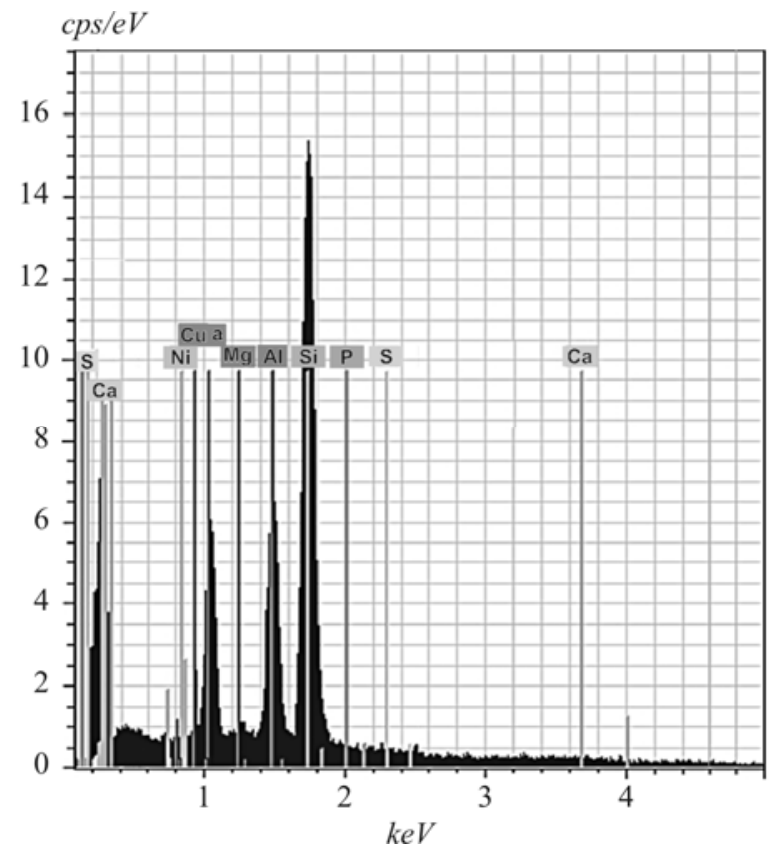

Figure 1. Chemical structure of a fine-disperse particle from an ambient air sample taken in residential area on the test territory

Note: $\mathrm{cps} / \mathrm{eV}$ is a number of impulses a 1 second per electron-Volt, keV is kilo-electron-Volt

${ }^{3}$ HS 2.1.6.3492-17. Maximum permissible concentration (MPC) of contaminants in ambient air in urban and rural settlements: The Order by the RF Chief Sanitary Inspector issued on December 22, 2017 No. 165. KODEKS: an electronic fund for legal and reference documentation. Available at: http://docs.cntd.ru/document/556185926 (07.02.2020) (in Russian). 


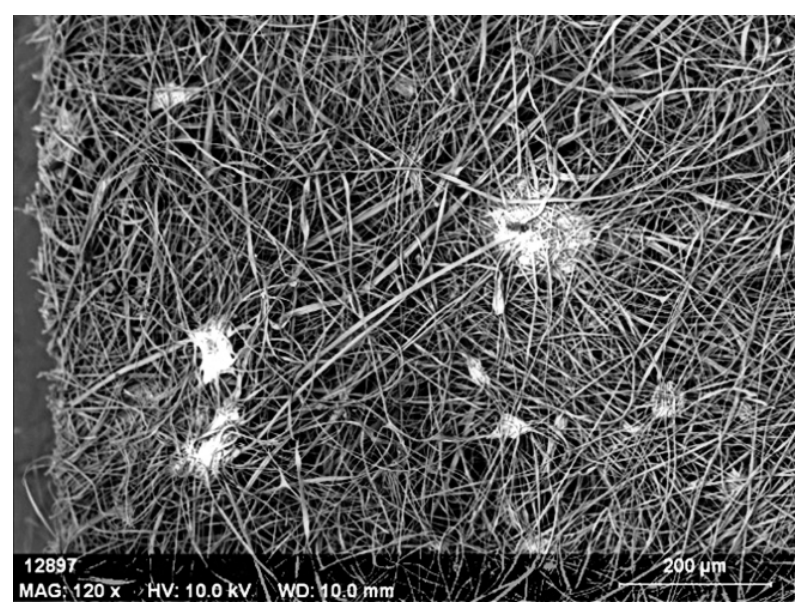

Figure 2. An image obtained with an electronic scanning microscope; it shows fine-disperse dust particles deposited on a filter during ambient air examination on the test territory (scale 120:1)

Morbidity among population was analyzed basing on data taken from state statistic reports issued in 2014-2018; the analysis revealed that respiratory diseases held the $1^{\text {st }}$ rank place both in the primary and overall morbidity among children on the test territory and the reference one as well. Overall morbidity with respiratory diseases amounted to $1,342.03$ cases per 1,000 children on the test territory and it was 1.8 times higher than the same parameter among children on the reference territory (760.95 cases per 1,000 thousand people, $p \leq 0.05$ ) (Table 3 ). Overall morbidity among children living on the test territory taken as per specific nosologies on average over 5 years was authentically higher than the same parameters among children living on the reference territory. As for specific nosologies, the figures were as follows: allergic rhinitis, 80.3 times higher; chronic diseases of the tonsils and adenoids, 14.8 times higher; asthma and status asthmaticus, 4.14 times higher $(p \leq 0.05)$.

A rather alerting trend is a growth (up to 1.7 times) in primary morbidity with respiratory diseases among children living on the test territory (1,274.97 cases/1,000 children) against the same parameter on the reference territory (752.03 cases/1,000 children) (Table 4). Primary morbidity with chronic diseases of the tonsils and adenoids over 5 years was 5.4 times authentically higher among children on the test territory among the reference one $(p \leq 0.05)$.

There were new cases of allergic rhinitis registered in children living on the testy territory in the analyzed period whereas there were no such cases among children living on the reference one. We didn't detect any authentic discrepancies as per other nosologies.

According to data on application for medical aid in 2017-2018, morbidity with respiratory diseases among children on average amounted to 1,426.46 cases/1,000 children and 788.99 cases/1,000 children on the test and reference territory accordingly, discrepancy was 1.8 times $(p=0.0001)$.

We assessed cause-and-effect relations within «ambient air quality - morbidity among children» system and it allowed us to reveal direct dependence between growing probability of respiratory diseases (as per data on application for medical health) and particulate matter concentrations $(a=0.534 ; \quad b=1.787 ; \quad r=0.19$; $p=0.001)$. A contribution made by particulate matter into respiratory disorders amounted to approximately $20 \%$.

Table 2

Chemical structure of some disperse particles in ambient air samples taken in residential areas influenced by metallurgic production

\begin{tabular}{|c|c|c|c|c|c|c|c|c|c|c|c|}
\hline \multirow{2}{*}{$\begin{array}{l}\text { Residential } \\
\text { area }\end{array}$} & \multirow{2}{*}{$\begin{array}{l}\text { Particles } \\
\text { size, } \mu \mathrm{m}\end{array}$} & \multicolumn{10}{|c|}{ Chemical structure, mas. \% } \\
\hline & & $\mathrm{Na}$ & $\mathrm{Mg}$ & $\mathrm{Ca}$ & $\mathrm{Al}$ & $\mathrm{Cu}$ & $\mathrm{Fe}$ & $\mathrm{Ni}$ & $\mathrm{Ti}$ & $\mathrm{Ga}$ & $\mathrm{Nd}$ \\
\hline \multirow{4}{*}{ Test territory } & 66.89 & 7.11 & 4.87 & 9.58 & 6.51 & - & 0.63 & - & - & - & - \\
\hline & 39.55 & 6.80 & 1.82 & 1.86 & - & 1.25 & 5.48 & 4.14 & - & - & - \\
\hline & 1.12 & 1.50 & 7.49 & 6.59 & 1.46 & 3.54 & 0.16 & 5.0 & 3.68 & 0.64 & 4.10 \\
\hline & 0.98 & - & - & - & - & 62.01 & - & 11.97 & - & - & - \\
\hline \multirow{3}{*}{$\begin{array}{l}\text { Reference } \\
\text { territory }\end{array}$} & 61.58 & - & 10.23 & 1.41 & 3.663 & - & 10.10 & - & - & - & - \\
\hline & 19.43 & - & 6.29 & 0.86 & 11.50 & 43.14 & - & - & - & - & - \\
\hline & 72.56 & - & 9.08 & 5.00 & 7.25 & - & 0.60 & - & - & - & - \\
\hline
\end{tabular}


Table 3

Overall morbidity among children on the test territory and the reference one over 2014-2018, cases/per 1,000 children

\begin{tabular}{|l|c|c|c|c|c|}
\hline \multirow{2}{*}{$\begin{array}{c}\text { Disease class / nosology } \\
\text { (as per ICD-10) }\end{array}$} & \multicolumn{2}{|c|}{ Test territory } & \multicolumn{2}{c|}{ Reference territory } & \\
\cline { 2 - 6 } & $\begin{array}{c}\text { Average over } \\
\text { 2ases per 1,000 } \\
\text { children }\end{array}$ & $\begin{array}{c}\text { Growth } \\
\text { rate, 2018 to } \\
2014, \% *\end{array}$ & $\begin{array}{c}\text { Average over } \\
2014-2018, \\
\text { cases per 1,000 } \\
\text { children }\end{array}$ & $\begin{array}{c}\text { Growth } \\
\text { rate, } \\
2018 \text { to } \\
2014, \% *\end{array}$ & $\begin{array}{c}\text { Validity of dis- } \\
\text { crepancies as per } \\
\text { mean value, } \\
\text { p } \leq 0.05\end{array}$ \\
\hline $\begin{array}{l}\text { J00-J98 Diseases of the res- } \\
\text { piratory system }\end{array}$ & $1,342.03 \pm 90.11$ & -3.30 & $760.95 \pm 20.14$ & -5.67 & $\leq 0.05$ \\
\hline $\begin{array}{l}\text { J30.1 Allergic rhinitis (pol- } \\
\text { linosis) }\end{array}$ & $10.44 \pm 1.25$ & -8.72 & $0.13 \pm 0.02$ & 0.00 & $\leq 0.05$ \\
\hline $\begin{array}{l}\text { J35-J36 Chronic diseases of } \\
\text { tonsils and adenoids }\end{array}$ & $49.84 \pm 8.52$ & 45.62 & $3.36 \pm 0.05$ & -68.55 & $\leq 0.05$ \\
\hline $\begin{array}{l}\text { J44 Other chronic obstruc- } \\
\text { tive pulmonary disease }\end{array}$ & $2.29 \pm 0.51$ & 287.55 & $1.55 \pm 0.21$ & -64.09 & 0.29 \\
\hline $\begin{array}{l}\text { J45-J46 Asthma, status } \\
\text { asthmaticus }\end{array}$ & $18.12 \pm 2.47$ & -33.77 & $4.37 \pm 0.85$ & 81.43 & $\leq 0.05$ \\
\hline
\end{tabular}

Note: * means that if a parameter was equal to zero in 2014 , growth rate was not calculated.

Table 4

Primary morbidity among children on the test and reference territory in 2014-2018, cases/per 1,000 children

\begin{tabular}{|l|c|c|c|c|c|}
\hline \multirow{2}{*}{$\begin{array}{c}\text { Nosology } \\
\text { (as per ICD-10) }\end{array}$} & \begin{tabular}{c}
$|c|$ \\
\cline { 2 - 6 } \\
\cline { 2 - 6 } \\
2014-2018, \\
cases per \\
1,000 children
\end{tabular} & $\begin{array}{c}\text { Growth rate, } \\
2018 \text { to } \\
2014, \% *\end{array}$ & $\begin{array}{c}\text { Average over } \\
2014-2018, \\
\text { cases per } \\
1,000 \text { children }\end{array}$ & $\begin{array}{c}\text { Growth rate, } \\
2018 \text { to } \\
2014, \% *\end{array}$ & $\begin{array}{c}\text { Validity of dis- } \\
\text { crepancies as per } \\
\text { mean value, } \\
\text { p } \leq 0,05\end{array}$ \\
\hline $\begin{array}{l}\text { J00-J98 Diseases of the res- } \\
\text { piratory system }\end{array}$ & $1,274.97$ & -1.21 & 752.03 & -3.40 & 0.30 \\
\hline $\begin{array}{l}\text { J30.1 Allergic rhinitis (pol- } \\
\text { linosis) }\end{array}$ & 1.47 & -40.97 & - & $-*$ & $\leq 0.05$ \\
\hline $\begin{array}{l}\text { J35-J36 Chronic diseases of } \\
\text { tonsils and adenoids }\end{array}$ & 16.66 & -24.98 & 3.07 & -90.21 & $\leq 0.05$ \\
\hline $\begin{array}{l}\text { J44 Other chronic obstruc- } \\
\text { tive pulmonary disease }\end{array}$ & 0.76 & 764.71 & 0.54 & -100.00 & 0.34 \\
\hline $\begin{array}{l}\text { J45-J46 Asthma, status } \\
\text { asthmaticus }\end{array}$ & 1.78 & -21.72 & 1.28 & 116.35 & 0.14 \\
\hline
\end{tabular}

N o te : * means that if a parameter was equal to zero in 2014 , growth rate was not calculated.

Our research results indicated that average daily concentrations of particulate matter were up to 5 times higher than maximum permissible ones fixed in hygienic standards recommended by the WHO; as for $\mathrm{PM}_{10}$ и $\mathrm{PM}_{2,5}$, their contents were up to 1.4 times higher. And it should be noted that $\mathrm{PM}_{2.5}$ and $\mathrm{PM}_{10}$ account for a big share (up to $57 \%$ ) of the overall particulate matter volumes in dust and gas emissions form met- allurgic production. It is well in line with opinions on the issue expressed by the WHO experts and also confirms data obtained by Russian scientists in their research works [18-20]. And particles with their size exceeding $1 \mu \mathrm{m}$ and containing specific metal oxides (nickel, copper, iron, titanium, gallium, and neodymium) can aggravate negative impacts exerted on the respiratory tract due to their toxicity. 
As per data taken from state reports and application for medical aid registered for children living on the test territory, both overall and primary morbidity among them was 1.7-1.8 times higher than among children living on the reference territory if taken as per respiratory diseases in general; it could be from 4.0 to 14.8 times higher if taken as per specific nosologies (chronic diseases of tonsils and adenoids, asthma and status asthmaticus). The obtained results coincide with data taken from foreign and domestic research works on epidemiologic assessment of impacts exerted by particulate matter in ambient air on respiratory diseases prevalence among children [7, 21, 22].

We detected direct dependence between elevated morbidity with respiratory organs diseases among children under aerogenic exposure to particulate matter and it allows us to assume there could be up to 500 additional disease cases annually per 1,00 children caused by the increased levels of the examined contamination factor. Use of scientifically grounded results which we obtained allows revealing cause-and-effects relations between living on a specific territory and diseases occurrence; in its turn, it helps make efficient managerial decisions aimed at reducing negative consequences for respiratory organs in children who live under aerogenic exposure to chemicals [23].

Particulate matter including $\mathrm{PM}_{10}$ and $\mathrm{PM}_{2,5}$, occur in ambient air on residential areas due to metallurgic enterprises located nearby; exposure to them results in apparent negative effects and it allows assuming there can be additional morbidity with respiratory diseases among children caused by particulate matter contents in ambient air as it has been confirmed by results obtained in this research work. Particulate matter contents in ambient air in industrial regions, including territories where metallurgic enterprises are located, can be efficiently reduced via updating the regulatory basis, in particular, fixing stricter standards for fine-disperse particulate matter contents in ambient air and developing techno- logical and sanitary-hygienic activities aimed at reducing emissions from primary emission sources. It is necessary to implement targeted medical and preventive activities for children who permanently live under aerogenic exposure to particulate matter; these activities should be aimed at reducing respiratory diseases cases.

\section{Conclusions.}

1. Hygienic assessment of ambient air quality regarding particulate matter contents revealed that existing $\mathrm{PM}_{10}$ and $\mathrm{PM}_{2.5}$ concentrations exceeded average daily maximum permissible ones as they were up to 1.2 and 1.4 times higher than MPCav.d. accordingly than hygienic standards recommended by the WHO.

2. Respirable particulate matter fraction has complex chemical structure and contains metals (nickel, copper, iron, titanium, gallium, and neodymium) that are specific for emissions discharged into ambient air by metallurgic enterprises; it can intensify negative effects produced by particulate matter on the respiratory organs.

3. Assessment of morbidity revealed higher primary and overall morbidity among children population on the test territory than among those living on the reference territory; it was up to 1.8 times higher if taken as per all respiratory diseases; it could be up to 14.8 times higher as per specific nosologies such as chronic diseases of tonsils and adenoids, and asthma and status asthmaticus against the same parameter among non-exposed children.

4. We proved there was dependence between probability of respiratory diseases and elevated particulate matter concentrations in ambient air; it allowed us to predict annually up to $500 / 1,000$ additional cases of respiratory diseases among children caused by aerogenic exposure to particulate matter.

Funding. The research work was accomplished due to funding obtained from the state budget and allocated to fulfill the tasks set by state authorities.

Conflict of interests. The authors declare there is no any conflict of interests. 


\section{References}

1. Osnovnye pokazateli okhrany okruzhayushchei sredy -2019 g. [Basic ecological parameters - 2019]. Federal'naya sluzhba gosudarstvennoi statistiki. 2019. Available at: https://www.gks.ru/bgd/regl/b_oxr19/ Main.htm (04.02.2020) (in Russian)

2. Golokhvast K.S., Khristoforova N.K., Kiku P.F., Gul'kov A.N. Granulometric and mineralogic analysis of suspended particles in the air. Byulleten' fiziologii i patologii dykhaniya, 2011, no. 40, pp. 94-100 (in Russian).

3. World Health Organization. Global Status Report on Noncommunicable Diseases 2014. World Health Organization. Available at: http://apps.who.int/iris/bitstream/10665/148114/1/9789241564854eng.pdf?ua/ (04.02.2020).

4. Traboulsi H., Guerrina N., Iu M., Maysinger D., Ariya P., Baglole C.J. Inhaled Pollutants: The Molecular Scene behind Respiratory and Systemic Diseases Associated with Ultrafine Particulate Matter. Int. J. Mol. Sci, 2017, vol. 24, no. 18 (2), pp. 243. DOI: 10. 3390/ijms18020243

5. Sarnat S.E., Winquist A., Schauer J.J., Turner J.R., Sarnat J.A. Fine particulate matter components and emergency department visits for cardiovascular and respiratory diseases in the St. Louis, Missouri-Illinois, Metropolitan Area. Environ. Health Perspect, 2015, vol. 123, no. 5, pp. 437-444. DOI: 10.1289/ehp.1307776

6. Kolpakova A.F., Sharipov R.N., Kolpakov F.A. The role of air pollution by the particulate matter in pathogenesis of the chronic noninfectious diseases. Sibirskii meditsinskii zhurnal, 2018, vol. 33, no. 1, pp. 7-13. DOI: 10.29001/2073-8552-2018-33-1-7-13

7. Revich B.A. Fine suspended particulates in ambient air and their health effects in megalopolises. PEMME, 2018, vol. XXIX, no. 3, pp. 53-78. DOI: 10.21513/0207-2564-2018-3-53-78

8. Beelen R., Raaschou-Nielsen O., Stafoggia M., Andersen Z., Weinmayr G., Hoffmann B., Wolf K., Samoli E. [et al.]. Effects of long-term exposure to air pollution on natural cause mortality: an analysis of 22 European Cohorts within the multi-centre ESCAPE project. Lancet, 2014, vol. 383, no. 9919, pp. 785-795. DOI: $10.1016 / \mathrm{S} 0140-6736(13) 62158-3$

9. Jantzen K., Møller P., Karottki D.G., Olsen Y., Bekö G., Clausen G., L.- Hersoug G., Loft S. Exposure to ultrafine particles, intracellular production of reactive oxygen species in leukocytes and altered levels of endothelial progenitor cells. Toxicology, 2016, vol. 359, no. 60, pp. 11-18. DOI: 10.1016/j.tox.2016.06.007

10. Atkinson R.W., Mills I.C., Walton H.A., Anderson H.R. Fine particle components and health a systematic review and meta-analysis of epidemiological time series studies of daily mortality and hospital admissions. Journal of Exposure Science and Environmental Epidemiology, 2015, vol. 25, pp. 208-214. DOI: $10.1038 /$ jes.2014.63

11. Carvalho-Oliveira R., Pires-Neto R.C., Bustillos J.O.V., Macchione M., Dolhnikoff M., Saldiva P.H., Garcia M., Bueno Garcia M.L. Chemical composition modulates the adverse effects of particles on the mucociliary epithelium. Clinics, 2015, vol. 70, no. 10, pp. 706-713. DOI: 10.6061/clinics/2015(10)09

12. Cohen A.J., Brauer M., Burnett R., Anderson H.R., Frostad J., Estep K., Balakrishnan K., Brunekreef B. [et al.]. Estimates and 25-year trends of the global burden of disease attributable to ambient air pollution: an analysis of data from the Global Burden of Diseases Study 2015. Lancet, 2017, vol. 389, no. 10082, pp. 1907-1918. DOI: 10.1016/ S0140-6736(17)30505-6

13. Lelieveld J., Evans J.S., Fnais M., Giannadaki D., Pozzer A. The contribution of outdoor air pollution sources to premature mortality on a global scale. Nature, 2015, no. 525, pp. 367-371. DOI: 10.1038 /nature15371

14. Nemenko B.A., Iliyasova A.D., Arynova G.A. Otsenka stepeni opasnosti melkodispersnykh pylevykh chastits vozdukha [Assessment of threats posed by fine-dispersed dust particles in ambient air]. Vestnik KazNMU, 2014, vol. 3, no. 1, pp. 133-135 (in Russian).

15. Glants S. Mediko-biologicheskaya statistika [Medical and biological statistics]. Moscow, Praktika Publ., 1998, 459 p. (in Russian).

16. Esposito S., Galeone C., Lelii M., Longhi B., Ascolese B., Senatore L., Prada E., Montinaro V. [et al.]. Impact of air pollution on respiratory diseases in children with recurrent wheezing or asthma. BMC Pulmonary Medicine, 2014, vol. 7, no. 14, pp. 130.

17. Fan X.J., Yang C., Zhang L., Fan Q., Li T., Bai X., Zhao Z.-H., Zhang X., Norback D. Asthma symptoms among Chinese children: the role of ventilation and $\mathrm{PM}_{10}$ exposure at school and home. The 
International Journal of Tuberculosis and Lung Disease, 2017, vol. 21, no. 11, pp. 1187-1193. DOI: 10.5588/ijtld.17.0196

18. WHO Air quality guidelines for particulate matter, ozone, nitrogen dioxide and sulfur dioxide: summary of risk assessment, 2005. World Health Organization. 2005. Available at: http://apps.who.int/ iris/handle/10665/69477 (07.02.2020).

19. Zagorodnov S.Yu., May I.V., Kokoulina A.A. Fine-disperse particles $\left(\mathrm{PM}_{2.5}\right.$ and $\left.\mathrm{PM}_{10}\right)$ in atmospheric air of a large industrial region: issues related to monitoring and standardization of suspended particles in industrial emissions. Gigiena i sanitariya, 2019, vol. 98, no. 2, pp. 142-147 (in Russian).

20. Zagorodnov S.Yu., Kokoulina A.A., Popova E.V. Studying of component and disperse structure of dust emissions of metallurgical complex enterprises for problems of estimation the population exposition. Izvestiya Samarskogo nauchnogo tsentra Rossiiskoi akademii nauk, 2015, vol. 17, no. 5 (2), pp. 451-456 (in Russian).

21. Petrov S.B., Onuchina E.N. Ecological and epidemiological estimation of influence of airborne particular matters in atmospheric air on prevalence of illnesses of respiratory organs in city children's population. Zdorov'e naseleniya i sreda obitaniya, 2011, vol. 6, no. 219, pp. 20-23 (in Russian).

22. Platikanova M. Comparative analysis of the impact on air pollution on the respiratory system of children in the municipalities of Stara Zagora, Galabovo and Gurkovo. Trakia Journal of Sciences, 2014, vol. 12, no. 1, pp. 417-419 (in Russian).

23. Saldan I.P., Shur P.Z., Ushakova A.A., Goleva O.I., Katunina A.S., Khasanova A.A. Statement of need to develop and implement medical and preventive care programs for population under exposure to chemical pollutants. Ekologiya cheloveka, 2015, no. 9, pp. 56-64 (in Russian).

Tikhonova I.V., Zemlyanova M.A., Kol'dibekova Yu.V., Peskova E.V., Ignatova A.M. Hygienic assessment of aerogenic exposure to particulate matter and its impacts on morbidity with respiratory diseases among children living in a zone influenced by emissions from metallurgic production. Health Risk Analysis, 2020, no. 3, pp. 60-68. DOI: 10.21668/health.risk/2020.3.07.eng

Received: 07.07.2020

Accepted: 21.09 .2020

Published: 30.09.2020 